\title{
Traditional Land Tenure System in Nnewi Anambra State, Nigeria
}

\author{
Chinedu Yhanata Okolo ${ }^{1}$, Joseph Ugochukwu Ogbuefi ${ }^{2}$ \\ ${ }^{I}$ Department of Estate Management \\ Nnamdi Azikiwe University PMB 5025, Awka, Anambra State, Nigeria. \\ ${ }^{2}$ Department of Estate Management \\ University of Nigeria, Enugu Campus.
}

\begin{abstract}
This paper examines the land tenure practices in traditional Nnewi community which is the only community in Nnewi North L.G.A., Anambra State, comprising four quarters. Some elders and community leaders were interviewed. Also secondary data were obtained from textbooks, journals and other published and unpublished online materials. This paper identified how land was acquired traditionally and the reasons for land acquisition/ownership in traditional Nnewi society. It also classified land tenure in traditional Nnewi society and also identified the traditional channels of settlement of land dispute in Nnewi. It concludes that the pattern of land tenure system practiced in Nnewi was one carefully drawn with a well organized system of land dispute resolution which has strata and jurisdiction. This system has been in existence as far back as 11 century $A D$ even before the coming of the British with their system of land tenure.
\end{abstract}

\section{Key WordS: Land Tenure System, Communal land, Land Acquisition.}

\section{INTRODUCTION}

Land is an indispensable natural resource to man because on it human activities take place. As activities of man increases the demand for land increases. Land is part of the culture of a people both at individual and communal level they are willing to fight and defend it. Throughout history, the ownership of land has often been a sensitive and politically controversial issue. Perhaps one reason for this is that land is unlike other commodities that can be bought and sold, in that it is fixed in location [1]. Land for the Igbo people has economic, socio-political and religious connotations as it is regarded by the people as a sacred gift from God for the good and maintenance of all members of the communities dead or alive. Thus, it is generally believed that "land belongs to a vast family of which many are dead, few are living, and countless members are still unborn" [2]; the living only hold land in trust for the benefit of their dead ancestors, themselves and generations yet to come. "Reference [3] also identified satisfying spiritual need, securing home base, satisfying economic need, profit, independence, prestige and political power, continuity and social benefit as the motives of owning land among the Igbos.

Land is known to have spiritual conation and value amongst the Igbos with Nnewi as no exception. Land is seen as the home of those ancestors who, more often than is realized, play an active and important part in the daily life of those still living. Nnewi Kingdom is also known as Anaedo meaning the Land of Gold (The supreme deity and goddess of Nnewi). There are instances in the study area where land is seen as a deity itself. For instance Edo is the supreme deity of all the Alusi (Igbo: deity) in the Anaedo country (Nnewi). The central shrine of this unifying Alusi is at Nkwo Nnewi; the central Market. There are four other deities in Nnewi: Ana (meaning land), Ezemewi, Eze and Ele.

According to "Reference [4], land tenure is the relationship, whether legally or customarily defined, among people, as individuals or groups, with respect to land. Land tenure is an institution, that is, rules invented by societies to regulate behaviour. Rules of tenure define how property rights to land are to be allocated within societies. They define how access is granted, the rights to use, control, and transfer land, as well as associated responsibilities and restraints. Land tenure systems determine who can use what resources for how long, and under what conditions.

Land markets exist when and wherever it is possible to exchange rights in land, usually for agreed amounts of money or other considerations. The commercialization of Nnewi has increased the demand for land for various uses. Thus making land in Nnewi a very tradable commodity. Agbo Edo, a forest land which belonged to Edo; 
DOI: $\underline{10.51386 / 25815946 / \mathrm{ijsms}-\mathrm{v} 4 \mathrm{i} 6 \mathrm{p} 101}$

Nnewi deity, was cleared to make way for the development of the market called Nkwo Nnewi market. The development of this market was instrumental to the fast development and boom of commercial activities in Nnewi.

The transitional system of land ownership in Nnewi includes; communal land (Ana Obodo), village land (Ana Ogbe), clan land (Ana Umunna) and Ani Alusi; the ones dedicated to the gods. The individual and family land tenure is alien to the traditional land tenure system in Nnewi as they are derived from the Ana Umunna. When one is ready to build a house or to cultivate, he approaches his Umunna (Kinsmen) who gives him land from the Ana Umunna. The land got from the Ana Umunna becomes personal land to the new holder and family land (Ana Ezinulo) to the sons of the new holder. In the traditional land tenure in Nnewi, most Nnewian get a portion of land for their building/mbubo (home gardens) and another portion ubi (out-station gardens) where they usually cultivate their farm products.

\section{HISTORICAL BACKGROUND OF NNEWI}

The origin of Nnewi can be traced back to 11 century AD. The town is named after 'ewi', which means a rabbit, and 'nne', or mother, meaning mother of rabbits. Nnewi is structured into four quarters - Otolo, Uruagu, Umudim and Nnewichi - named after tribal descendants headed by Obi, the chief of the quarter. Nnewi was the eldest of four sons of Ikenga and Maku, whose four sons were Otolo, Uruagu, Umudim and Nnewichi and who gave their names to the four quarters of the town. Otolo is the eldest son, Uruagu is the second son, while Umudim and Nnewichi are the third and last sons respectively. According to oral historians, Oraifite and Ichi who are descendants of Ikenga founded the two other adjoining settlements and gave their names to these settlements. The traditional ruler of Nnewi is called the Igwe and the traditional stool is purely hereditary.

His Royal Highness Kenneth Orizu III is the current Igwe of Nnewi, he presides over the affairs of Nnewi. $\mathrm{He}$ is assisted by the traditional rulers (Obis) of the other three quarters; Uruagu, Umudim and Nnewichi. History revealed that Nnewi was known for trading economic goods and slaves in the 14th to 19th century due to external influence of the British and the Europeans in West Africa. The slave trade paved way for Christian missionaries (who followed British colonial administrators) to evangelize. The activities of the missionaries and British colonists brought about western civilization in the town. It was said that Christianity brought about a lot of positive change which was germen to the development of the town. Also, the Nigerian civil war of 1966-1970 contributed to the growth of Nnewi. Fleeing Igbos from the northern part of Nigeria during the war migrated to Nnewi. Presently, residents of Nnewi, like other towns in Igboland, are predominantly Christian. However, there still exist a small number of traditional worshippers among the population. Traditions and norms of the Igbos regarding patriarchy, marriage, land, cultural ceremonies and activities and outlook on life are still upheld in some sectors of the community [5].

\section{THE CONCEPT OF LAND}

"Reference [6] postulated six concepts of land to include: physical, economic, legal, socio-political, spiritual and abstract. He opined that the meaning of land can be best explained through the conceptual framework expressed by the major players in land use decision namely: economists, lawyers, geographers, supernatural persons and governing institutions.

\section{A. The Physical Concept}

Physical land is concerned with the natural environment in which man finds himself and the nature and characteristics of various resources with which he must work. It comprises the physical solum (soil) and all manmade resources and environment on land together with the sub-surface and supra-surface areas of the earth surface. It takes account of the vegetation, sunshine, rainfall and topographic features etc. that either help or hinder man in his use of land.

\section{B. Economic Concept}

Land in economics refers to the entire natural and man-made resources, which possession of the earth's surface gives control over. Land is seen as a factor of production as well as bedrock of all wealth. Classical economists see land as space, factor of production, consumption good and capital. 
DOI: $\underline{10.51386 / 25815946 / \mathrm{ijsms}-\mathrm{v} 4 \mathrm{i} 6 \mathrm{p} 101}$

Volume: 4 Issue: 6

November to December 2021

https://www.ijsmsjournal.org

\section{Legal Concept}

The legal concept of land quantifies the abstract concept of land and determines the quantum of the rights and interests, which somebody may claim over land.

\section{Abstract Concept}

This concept is built on the abstract or invincible attribute of a proprietary land unit, the decision making unit of the land. According to "Reference [4] the proprietary land unit is created by the prevailing land tenure system. The abstract elements of land are invisible attributes of a proprietary land unit, which greatly influence the basis for economic use of the physical land.

\section{E. Socio-Political Concept}

This concept deals with the human element of land. It looks at land as situation pertaining to people from the community as against the physical environment. It tries to classify the geographical location of land or territories into political unit or socio-political entity. Typical socio-political group in any community include: family unit, village/community/kingship, town, country and continent.

\section{F. Spiritual/Religious Concept}

The acceptance of the concept of land depends on the belief of people, throughout the world, people have always attached certain things to land, which often make it to be sacred. The Igbos of Eastern Nigeria view land as a deity. It is the belief of the people that as a deity land exercises inherent control over the people.

\section{Traditional Methods of Land AcQuisition}

The tenureship of land differs slightly from society to society. "Reference [7] identified first settlement, conquest, customary grants, gift, inheritance and sales as methods of land acquisition.

\section{A. First Settlement}

A settler or group of settlers such as a community or family who settled down first on a parcel of land free from any other adverse claim or challenge; such settler(s) is(are) seen as an adverse owner. Most lands were originally acquired through this means. For instance history has it that Nnewi is a migrant from Orlu, who migrated and settled in the present Nnewi in the 11 AD.

\section{B. Conquest}

Community/village wars were used as means of acquiring land in the pre-colonial times. Acquisition of land by conquest was possible under the native laws and customs. The conqueror became the owners of the land. This is no longer obtainable in most places including towns and communities in Nigeria.

\section{Customary Grants}

This is a process whereby the community through the community heads issue land to individuals, usually members of the community. Land is only granted to the male children. Previously in Nnewi, land was granted to male children who were ready to build where they will live with their families. Currently due to the scarcity of land few remaining communal lands are now been used for communal purposes such as the development of markets or town halls.

\section{Gift}

This is the transfer of land from one person to another without the payment of any consideration. The community or an individual can gift land especially for developmental purposes. For instance His Royal Highness Igwe Dr. Kenneth Onyemaeke Nnaji Orizu III donated most of the lands used for the establishment of the College of Health Sciences, Nnamdi Azikiwe University, Nnewi.

\section{E. Inheritance}

This is one of the predominant methods of land acquisition. It is the devolution of land from one person to another, especially from a father to a son. In most Igbo traditional communities with Nnewi as no exception, the aniobi (father's compound where he lived) is inherited by the Diokpala (first son). If the father has other lands he issues them to his other sons, if he does not have any other land and the compound is large enough, his other sons can get portions of it for the development of their own houses. The particular portion where the father 
DOI: $\underline{10.51386 / 25815946 / \mathrm{ijsms}-\mathrm{v} 4 \mathrm{i} 6 \mathrm{p} 101}$

Volume: 4 Issue: 6

November to December 2021

https://www.ijssmsjournal.org

developed his own house (aniobi) is inherited by the first son. Likewise in some communities like Nnewichi if the mother's kitchen was built outside the main house (just as we used to have it in the old traditional settings), the last son is expected to inherit the mother's kitchen and out-house (animpuke).

\section{F. Sale}

This is the transfer of interest in land by a seller to a purchaser for some consideration. This consideration could be in the form of money and/or other items such as kola nuts, goat and palm wine.

\section{DEMAND FOR LAND}

In traditional Nnewi Communities land is required for various purposes which indirectly affect the tenures system and they includes: housing, farming, recreation, worship and other uses. The following are the reasons for the demand for housing;

A. Housing: land has always been demanded for the provision of shelter to man. The increase in economic activities in Nnewi due the presence of Afia Nkwo (Nkwo Nnewi Market) and other economic and social institutions has led to increased population and hence more demand for land for housing and other purposes.

B. Farming: traditionally in the past the Nnewi community was known for peasant farming which helps them to take care of their families. Each household usually had the ana mbubo; which is a garden around the house where daily food items are cultivated such as bitter leaves, pumpkin lease and paper. It also served as a place for the disposal of biodegradable waste such as kitchen waste and dry leaves. Individual households also had the Ana ubi (out-stationed land) where they do their main farming and cultivate crops such as cassava and yam.

C. Recreation: Nnewi has various village squares which are used for social gatherings. These village squares are still in existence. There are village squares located in the various palaces of the Obis (kings) such as Obi Otolo, Obi Umudim, Obi Uruagu, Obi Nnewichi. The villages in these four quarters (communities) also have their various smaller Obis which also have market squares. For instance Nnewichi has Obi Oduda, Obi Abubor, Obi Okpuno and Obi Obiofia. The various shrines also have their squares where the traditional worshipers gather.

D. Worship: Nnewi still accommodates many shrines and churches. Some of these shrines are as old as Nnewi itself, since 11AD. Few persons are still traditional worshipers and make use of these shrines. Some examples of the shrines are: Okwuana in Umuanuka Otolo Nnewi, Okwuezemewi in Abubor Nnewichi, Okwuogwugwu in Okpuno Nnwichi, Okwumkpukpa in Umunem Otolo Nnewi and many others.

\section{Classification of Land Tenure in Traditional Nnewi Society}

Historically, in Nnewi land was held communally, however, this pattern of land ownership or land tenure has given way to individually held pieces and parcels of land. The tenure system in traditional Nnewi society is a peculiar one; however for the purpose of this work, different tenure practices in traditional Nnewi society may be seen as discussed below:

\section{A. Communal Land Tenure (Ana Obodo)}

The communal land tenure system in traditional Nnewi society has been in existence before the enactment of various land tenure laws in Nigeria. This is evident in the various lands dedicated for various communal use and which includes the village squares, the shrines, the market and other land dedicated for farming purposes. Historical evidence has shown that Nnewi in the past fought wars just to increase her size of communal land. One can gain access to community land by being a member of the community. In this type of tenure the land is owned by the entire Nnewi communities which can be shared among the four quarters/communities; the four quarters comprise of Otolo, Umudim, Uruagu and Nnewichi hence the Ana Otolo Ana Umudim, Ana Uruagu and Ana Nnewichi. Ownership of some of these lands are still held communally by the four quarters, an example is the Nkwo Triangle. The Nkwo Triangle being owned by the entire Nnewi community is held in trust and administered by the Igwe Orizu of Nnewi together with the other three Obis, while the lands owned by the individual quarters are held in trust and administered by the Obis of those quarters, an example is the Ani Nkwo Nnewichi which is administered by the Obi of Nnewichi. 
DOI: $\underline{10.51386 / 25815946 / \mathrm{ijsms}-\mathrm{v} 4 \mathrm{i} 6 \mathrm{p} 101}$

\section{B. Village Land (Ana Ogbe)}

The various community/quarter lands can further be shared among the villages that make up each community/quarter while some are retained as community land. Village land emanates from the community land. The villages comprises of different clans (Umunna), the Umunna comprises of larger extended families. For instance in Nnewichi community there are four villages which include: Oduda Nnewichi, Abubor Nnewichi, Okpuno Nnewichi and Obofia Nnewichi. Each of the four villages own lands known as Ani Ogbe. The Ani Ogbe is held in trust and administered by the Obis of the various villages.

\section{Clan Land (Ana Umunna)}

This emanates from the Ani Ogbe. The various villages in Nnewi has various clans, for instance Oduda Nnewichi village has six clans which include: Umunna Ezekwolobi, Umunna Umudalu, Umunna Eziodida, Umunna Enenwu and Umunna Ezechiedo. These six clans all have their own land, which they allocate to members of their clan if need be. The Umunna has an elected head known as Onyeisi Umunna (Chairman of Umunna), he spearheads the activities of the umunna including land matters. He works with the Isiokolo also known as Onauto, who collects utu (levies) from members of the umunna and disseminate information. The first Umunna (Isi Umunna) also has a hereditary head known as the Obi Umunna, who is also the head of the village and thereby the head of all the Umunnas in his village. In Oduda Nnewichi the head of Umunna Ezekwolobi, that is, the Obi of Ezekwolobi, is also the Obi Oduda. He is charged with resolving land disputes among any member of the clans under his village.

\section{The Family Land (Ana Ezinauno)}

Some family land emanates from the clan land. This is so because when a man is allocated a parcel of land by the Umunna, the allotted land is also inherited by his sons. Family land is owned by a family in a certain prescribed manner by the head of the family which is usually the oldest member of the family. He holds the same in trust for the rest members of the family. Despite the fact that the family head possesses the right to family land, he cannot take decisions in respect of the land such as alienating, leasing or disposal of the land without the consent of the principal members of the family. He must seek the opinion of the principal members of the family before taking decision on land. In the Igbo tradition all sons are entitled to their father's compound with the eldest son acting as a caretaker until all the other sons have built their own house and vacate the compound which now wholly belongs to the eldest son. There is also the following:

1) Ana Iru Ezi (Front View of Compound): This is also known as the obi and is the exclusive birthright of the eldest son (Di Okpala).

2) Mkpuke: These are huts built for wives behind the compound which usually includes the woman kitchen. The last son of the woman inherits his mother's mkpuke.

3) Uzo Mkpa: These are small track roads between the compounds which usually link the compounds of extended families. In modern times, most of these tracks have been closed by block wall fencing.

\section{E. Individual Land Tenure}

The individual land emanates from the family land, where a father shares his land amongst his sons it becomes individual land. This individual land can also turn out to become family land if it will be further shared by the grandsons.

\section{Description of the Traditional Method of LAND TransaCtion In NNEWI}

In the olden days land was not seen as a tradable commodity in Nnewi but was seen as a commodity that can be given, hence the saying "adihi ere ana ere, ana enye ya enye". One can give another land for some certain considerations. For instance a man without children can give another person his land with the promise that the person will bury him and perform all burial rites upon his death. Another instance could be a man giving his land to a rich man with the promise that the rich man will train his child in school. Likewise, before the coming of the British the people of Nnewi practiced traditional mortgage (Igba mbibi), where one could use his land as collateral to take loan from another and gets back his land after payment. Such arrangements were done through 
DOI: $\underline{10.51386 / 25815946 / \mathrm{ijsms}-\mathrm{v} 4 \mathrm{i} 6 \mathrm{p} 101}$

Volume: 4 Issue: 6

November to December 2021

https://www.ijssmsjournal.org

oral evidence and in the presence of a witness(es). In Nnewi land could be given to someone who is not a member of the community but land was not given to women including women that are indigenes of the community.

There are three major items that must be present in every traditional land transaction in Nnewi, they are: eight kolanut (oji mkpuru isato), palm wine and goat. If a goat is killed, it means that the purchaser bought the land outrightly. The purchaser of the land takes a full leg of the goat while the seller takes the other parts of the goat. Some of these customary practices are still in practice, land sellers still demand for kolanuts and goat (ewu ana) as part of the consideration for the sale of their land.

\section{VIII.TRAditional Method OF RESOlVING LAND DiSPUTE IN NNEWI}

Land has always been a subject of dispute in our society. This is not just peculiar to the Igbos but is found among different tribes and people all over the world both in traditional and modern settings. Land dispute in Nnewi can be settled according to the customs and traditions of Nnewi people, especially where such dispute is among indigenes and the land is held customarily. There are hierarchies in the settlement of land disputes in Nnewi and these hierarchies have jurisdiction. It is important to note that this system and high level of organization has been in practice even before the coming of the British that brought The Received English Law and its court system.

Land disputes among members of the same extended family are settled by the Ime Nne (Larger Family) which is spearheaded by the eldest man in that extended family. If any party is not satisfied with the judgment at this level, he can take (appeal) the matter to the Umunna (presided by the Obi of Umunna or the Chairman of the Umunna), if he is not satisfied with the Umunna's judgment he can take it to the village (presided by the Obi of the village), if he is not satisfied at this level, he takes it to the quarters/community (presided by the Obi of the quarter/community) up until he gets to the Nnewi community level, which is presided by the Igwe Orizu of Nnewi and this is the final level. If the dispute is among kinsmen (Umunna), it starts from the Umunna level up until it gets to the Igwe. If it is among members of the same village it starts at the village level up until it gets to the Igwe. If it is among members of the same quarter it starts at the quarter level after which it gets to the Igwe. If it is among members of different quarters, then the dispute can only be settled by the Igwe. Also parties cannot jump a strata of settlement, it is expected that parties in dispute must have harnessed the lower strata before going to a higher authority.

Likewise, the location of the land in dispute determines which traditional ruler has the right/jurisdiction of settlement. The Obi of Nnewichi cannot settle a land matter in Umudim, neither can the Obi of Oduda settle a land matter in Abubor. It is also necessary to note that the Igwe, Obis and family heads do not settle this land matters in isolation, they work with other members of their cabinet/elders in the settlement of land dispute and other disputes.

The chart developed by the author as shown in Fig 1, helps elucidate the various hierarchies:

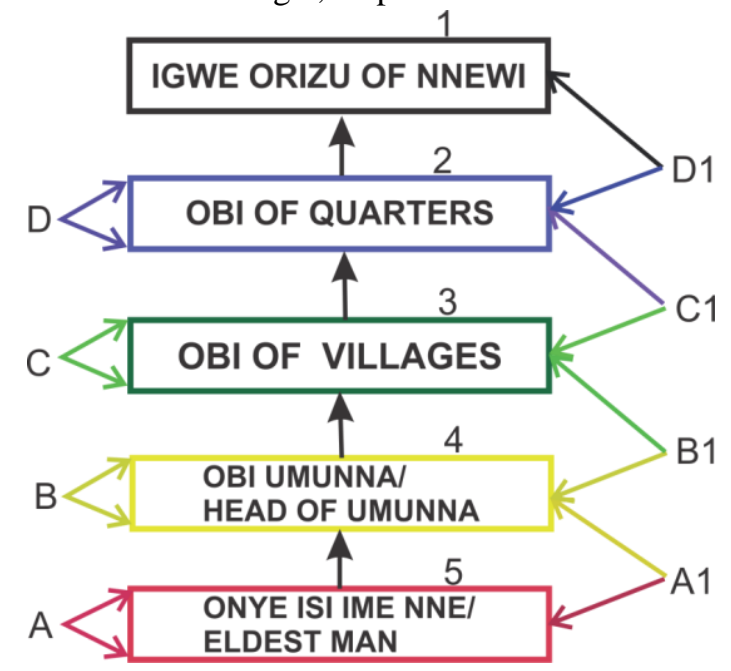

Fig 1: Hierarchies/Jurisdiction of Land Dispute settlement in Nnewi 
DOI: $\underline{10.51386 / 25815946 / \text { ijsms-v4i6p101 }}$

Volume: 4 Issue: 6

November to December 2021

https://www.ijsmsjournal.org

"A" represents a land dispute among family members, which could be resolved at the Imenne level.

"A1" represents a land dispute between people of different Imenne but the same Umunna, which could be resolved at Umunna level.

" $\mathrm{B}$ " represents a land dispute between people of the same Umunna, which could be resolved at the Umunna level.

"B1" represents a land dispute between people of different Umunna but the same village, which could be resolved at the village level.

"C" represents land dispute between people of the same village, which could be settled at the village level.

"C1" represents land dispute between people of different village but the same quarters, which could be settled at the quarter level.

" $D$ " represents land dispute between people of the same quarter, which could be settled at the quarter level.

"D1" represents land dispute between people of different quarters but the same community, which could be settled only at the community level.

" 1 " has jurisdiction over 2,3,4 and 5, but it must flow from 5,4,3 and 2 before it gets to " 1 ".

" 2 " has jurisdiction over 3,4 and 5, but it must flow from 5,4 and 3 before it gets to " 2 ".

" 3 " has jurisdiction over 4 and 5 , but it must flow from 5 and 4 before it gets to " 3 ".

" 4 " has jurisdiction over 5 , but it must flow from 5 before it gets to 4 .

"5" has jurisdiction only over 5.

\section{Conclusion}

This work has shown that various means of land acquisition has been in existence in Nnewi before the coming of the British which includes gift, inheritance, first settlement, sales, conquest and customary grant. It also showed that land is owned at different levels such as, ANAOBODO, ANAOGBE, ANAUMUNNA NA ANA EZI NU UNO.

Findings also indicates that Nnewi has a well organised hierarchy of land settlement which defines various jurisdiction based on parties involved in the dispute and location of the land in contention.

Also the study identified items such as palmwine (nkwu enu), 8 kolanuts (oji) and goat (ewu ani) as the items used in land transaction in Nnewi. Some or all of these items are still demanded when one wants to purchase land in Nnewi.

\section{References}

[1] R. Mahoney, P. Dale, and R. McLaren, "Land markets - Why are they required and how will they develop?" International Federation of Surveyors., vol 7, pp. 1-11, July 2007.

[2] N. Madumere, "Dynamics in Nigerian land administration system and the Conference Proceedings, 2019. p. 245. doi:10.5281/zenodo.3267694

inevitability of decentralization," in RAIS

[3] J.U. Ogbuefi, "Analysis of motives for land ownership among the Igbos of South Eastern Nigeria," A Multi-Disciplinary Journal for the Environmental Sciences., vol. 3, pp. 410-418, Aug. 2000.

[4] I. Osita,"An analysis of Igbo traditional land tenure system in Amawbia (Amobia), Awka South Local Government Area of Anambra State," International Journal of Engineering Science Invention., vol. 3, pp. 24 - 38, Jan. 2014.

[5] (2009) The UN-HABITAT website. [Online] Available: http://www.unhabitat.org

[6] J.A. Umeh, Compulsory acquisition of land and compensation in Nigeria. London, United Kingdom: Sweet and Maxwell, 1973.

[7] P. Joel. (2016) Ibejulekkilawyer blog homepage. [Online]. Available: http://www.ibejulekkilawyer.com/land-acquiring-methods-innigeria/ 